\title{
A PARTICIPAÇÃO DO FARMACÊUTICO CLÍNICO NA EQUIPE INTERDISCIPLINAR: RELATO DE CASO
}

\section{INTRODUÇÃO}

A inserção do farmacêutico clínico na equipe interdisciplinar torna-se importante no monitoramento farmacológico, nas decisões do plano terapêutico com o objetivo de uma terapia segura.

\section{RELATO DE CASO}

Paciente A.M.B. 63 anos, sexo masculino, procurou o hospital privado no interior de São Paulo, com queixas de cefaleia intensa há 4 dias e diplopia. Foi internado com e diagnóstico de meningite criptocócica. Iniciou tratamento com Anfotericina B Desoxicolato $50 \mathrm{mg}$ (Anfo B), dipirona, hidrocortisona. Após 15 dias de utilização de Anfotericina B Desoxicolato, dose acumulada de $750 \mathrm{mg}$, o tratamento foi substituído por Fluconazol $800 \mathrm{mg}$ devido a piora da função renal. Durante a infusão paciente apresentou reações adversas e piora clínica. Interrompido Fluconazol e alterado tratamento para Anfotericina B Lipossomal $350 \mathrm{mg}$ em 2h. Antes da infusão de Anfotericina B Lipossomal, medicamentos pré foram administrados a fim de diminuir os eventos adversos: hidrocortisona, tramadol e dipirona. Durante a infusão da Anfotericina B Lipossomal, o paciente relatou dores musculosqueléticas, e o tratamento foi suspenso. Prescrito novamente Fluconazol $800 \mathrm{mg}$. Após 4 dias, o paciente evoluiu com piora clinica e o tratamento foi suspenso. Introduzido novamente Anfotericina B Lipossomal com redução da dose para $100 \mathrm{mg}$ em $6 \mathrm{~h}$ (2 mg/10 min). Paciente apresentou a mesma reação, e tratamento foi interrompido. Após discussão com a equipe interdisciplinar (médico, farmacêutico clínico, enfermeiros) a dose de Anfotericna B Lipossomal foi reduzida para $50 \mathrm{mg}$ em $6 \mathrm{~h}(1 \mathrm{mg} / 10 \mathrm{~min})$; foi alterada a ordem de infusão dos medicamentos pré Anfotericina B Lipossomal, considerando o tempo de início de ação de cada fármaco e incluído uso prévio de Petidina. Desta maneira foi possível completar toda infusão da Anfotericina B Lipossomal. Discutido sobre os riscos de dependência psíquica associada ao uso da Petidina. Médico substitui Petidina por tramadol ( $2 \mathrm{~h}$ antes da Anfotericina B Lipossomal). Após estas intervenções a dose foi aumentada progressivamente até $350 \mathrm{mg} /$ dia e o paciente recebeu o tratamento por 10 dias, sem apresentar eventos adversos.

\section{REFERÊNCIAS}

\begin{tabular}{|c|c|}
\hline & Ações da Equipe Interdisiciplinar \\
\hline 1 & $\begin{array}{l}\text { - } 15 \text { dias de utilização de Anfotericina B } \\
\text { Desoxicolato } 50 \text { mg/dia (dose acumulada 750mg) }\end{array}$ \\
\hline 2 & $\begin{array}{l}\text { - } \quad \text { Suspenso Anfoterina B Desoxicolato } \\
\text { - } \quad \text { Substituído por Fluconazol } 800 \text { mg devido a piora } \\
\text { da função renal }\end{array}$ \\
\hline 3 & $\begin{array}{l}\text { - Interrompido Fluconazol devido a reações } \\
\text { adversas e piora clínica } \\
\text { - Alterado tratamento para Anfotericina B } \\
\text { Lipossomal } 350 \mathrm{mg} \text { em } 2 \mathrm{~h}+\text { pré medicação: } \\
\text { hidrocortisona, tramadol e dipirona }\end{array}$ \\
\hline 4 & $\begin{array}{l}\text { - Suspenso Anfotericina B lipossomal devido ao } \\
\text { paciente apresentar dores musculosqueléticas } \\
\text { durante a infusão } \\
\text { - } \quad \text { Prescrito Fluconazol } 800 \mathrm{mg}\end{array}$ \\
\hline 5 & $\begin{array}{l}\text { - Suspenso Fluconazol após } 4 \text { dias devido a piora } \\
\text { clínica. } \\
\text { - Introduzido novamente Anfotericina B } \\
\text { Lipossomal: } \\
\quad \text { redução da dose para } 100 \mathrm{mg} \mathrm{em} 6 \mathrm{~h} \mathrm{(2} \\
\quad \mathrm{mg} / 10 \mathrm{~min})\end{array}$ \\
\hline 6 & $\begin{array}{l}\text { - Suspenso Anfotericina B Lipossomal devido ao } \\
\text { paciente apresentar dores musculosqueléticas } \\
\text { durante a infusão }\end{array}$ \\
\hline 7 & $\begin{array}{l}\text { - Introduzido novamente Anfotericina B } \\
\text { Lipossomal: } \\
\text { redução da dose para para } 50 \text { mg em } 6 \mathrm{~h} \\
(1 \mathrm{mg} / 10 \mathrm{~min}) \\
\text { alterada a ordem de infusão dos } \\
\text { medicamentos pré Anfotericina B } \\
\text { Lipossomal, considerando o tempo de } \\
\text { início de ação de cada fármaco: } \\
\text { - } \quad \text { Tramadol (2 horas antes da } \\
\text { - } \quad \text { Hidrotericina B Lipossomal); } \\
\text { - Anfotericinana B Lipossomal); } \\
\text { Dipirona (após hidrocortisona) }\end{array}$ \\
\hline 9 & $\begin{array}{l}\text { - A dose de Anfotericina B Lipossomal foi } \\
\text { aumentada progressivamente até } 350 \mathrm{mg} / \text { dia e o } \\
\text { paciente recebeu o tratamento por } 10 \text { dias }\end{array}$ \\
\hline 10 & $\begin{array}{l}\text { - Desfecho clínico: alta hospitalar após } 38 \text { dias de } \\
\text { internação }\end{array}$ \\
\hline
\end{tabular}

\section{CONCLUSÃO}

A inserção do farmacêutico clínico na equipe interdisciplinar contribuiu com informações importantes ao tratamento proposto. A interação positiva dos membros da equipe culminou na melhora clínica e laboratorial do paciente com desfecho clínico de alta hospitalar após 38 dias de internação. 